\title{
CORRELATION BETWEEN THE PENETRATION STRATEGIES AND MARKETING MIX OF INTERNATIONAL HOTEL CHAINS IN ROMANIA
}

\section{Cosma Smaranda Adina, Fleșeriu Cristina, Bota Marius}

(1) Department of Hospitality, Babeş-Bolyai University, Cluj-Napoca

(2) Department of Hospitality, Babeş-Bolyai University, Cluj-Napoca

(3) Department of Hospitality, Babeş-Bolyai University, Cluj-Napoca

Professor dr. Cosma Smaranda Adina,

Babeş-Bolyai University Department of Hospitality, Cluj-Napoca, Romania smaranda.cosma@tbs.ubbcluj.ro

Article info

Paper category: Review Received: 23.6.2016. Accepted: 22.2.2016. JEL classification: L83, M31 


\begin{abstract}
On the Romanian market there are 21 international hotel chains, having 51 hotels. The goal of the research paper is to analyze which are the marketing mix policies and strategies used by the hotels, belonging to an international hotel chain on the Romanian market. For this purpose, a descriptive research was implemented through investigation of all the hotels that are part of an international hotel chain. The research reveals that hotels operate by abiding the norms established by contract. The higher the risk, the investment and control are, the more influence the hotel chain has regarding the pricing strategies. Hotels use their own channels but also the parent chain channels. Promotion strategy takes into account global, regional and local issues encountered. The majority of the hotels have the possibility to decide some internal elements for their personnel. All the hotels apply norms and standardized procedures regarding the quality of the services. The most expected advantage for a hotel that belongs to an international chain is the visibility at international level.
\end{abstract}

\title{
Keywords:
}

international hotel chains, hotel strategies, marketing mix strategies, international hotel 


\section{INTRODUCTION}

Hotel industry is one of the biggest and most competitive industries in the world. The current size of the hotel industry is challenging to quantify, but nonetheless, it demonstrated tremendous growth during the last quarter of a century (Jones, Hillier and Comfort, 2014). The hotel industry is viewed not only as one of the most globalized service sectors, but also as a prime actor in the development of globalization around the world (Yu et al., 2014). At the international level hotel market is characterized by take-overs, consolidations and expansions (Călăretu, 2011). As growth rates slow in the developed markets hotels are turning their attention to new and emerging markets in order to develop their businesses. Because of the favorable political climate and economic opportunities, in the last 25 years the hotel industry from Central and Eastern Europe faces with a significant expansion of the local hotel markets and operations of the international hotel chains.

Many of the international hotel chains use a mix of penetration strategies to expand into foreign markets. They are combing the foreign direct investment through acquisitions and constructions with the leased contract, the franchise, the management contract or even joint venture, based on the interest that they have in a specific country or based on the policies and regulations applied in that country (Bradley, 2001: 281; Johansson, 2006: 127-129; Guillet, Zhang and Gao, 2011).

Hospitality customers seek familiar services, which allow them to move easily between countries (Cline, 2002). International hotel chains often use synchronized marketing strategies, similar tangible and intangible services, and standardized environment and services for all of their locations (Aliouche and Schlentrich, 2011; Sutthijakra, 2011). Furthermore, after entering into a market, some of the hotel chains are using a standardized marketing mix and sell almost the same products, having the same marketing approach as in the rest of the world. These hotels benefit from scale economies and concentrate in marketing activities. Other want to make a difference between the markets and to adapt all the marketing mix elements to the desires and needs specific to the market that they would like to penetrate (Wilson and Gilligan, 2005: 319). Thus, globalization leads to standardization of services and processes within the hospitality industry. Standardization does not mean that a service is delivered in a strict mechanical way (Wilson, Zaithaml, Bitner \& Gremler, 2012), but on the contrary, standardization is a way to perform according to the expectations of customers. The importance of standardization is underlined by Wilson et al. (2012) because in hotel industry it is important to ensure the same level of service to all customers. Customization, as a process of delivering unique service in terms of types and quality, is regarded as a deliberate strategy for the hotel actors and can be used a way to adapt to the historical, and geographical particularities of a given market (Lee, 2011; Yu et al., 2014). Customization also is common for business-to-business level of service transactions (Wilson et al., 2012). 
Several studies investigated different entry and growth strategies implemented by the hotel chains for international markets, but there is a gap in the area of academic knowledge regarding marketing strategies used for emerging markets from Central and Eastern Europe. The goal of the paper is to identify and analyze if the marketing mix polices and strategies are adapted or standardized to the penetration strategies. The marketing mix variables considered in the present study are those proposed by Booms and Bitner. They had added to the classical elements of the marketing mix (product, price, place and promotion) other three elements for services industry: people, process and physical evidences (Booms and Bitner, 1980).

The present research investigates the Romanian hotel market. At this moment, on the Romanian market there are 21 international hotel chains, having $5^{1}$ hotels (3,6\% form the total hotel market). Also, these chains belong to international hotel groups (Cosma, Fleșeriu and Bota, 2014).

\section{METHODOLOGY}

The paper is based on a wider marketing research that aims to identify the perceptions and actions of hotels running under the umbrella of a hotel chain, upon the tourism industry in Romania. For this purpose, a descriptive research was made to identify the internal and the external factors that have an influence upon the activity of international chains as well as the marketing policies they use. As a research method, the investigation was performed. The interview for data collection was performed in all three forms: face to face, by telephone and by mail. The investigated population has included $5^{1}$ research units, representing all the hotels from Romania that are part of an international hotel chain (100\%). For information accuracy, the research had an overall character, though the opinion poll was excluded. Involving an elaborate data collection and processing work, the research lasted about three months and was conducted at the end of year 2013 and the beginning of the year 2014.

As data collection instrument it was used a questionnaire made up of 25 questions that wanted to identify several issues concerning the reason for which the hotels belonging to international hotel chains in Romania have decided to run under the umbrella of a certain brand making use of a certain penetration strategy as well as issues regarding the marketing strategies applied to the Romanian market. It has been tested if the chosen penetration strategy has a significant influence on the level of standardization or adaptation in respect with the marketing mix strategies implemented by hotels. As the variables considered are categorical nominal qualities, as statistical analysis instruments Chi and Cramer V were considered. The software applied for analysis was SPSS.

This paper capitalizes only a part of the data collected in this marketing research. The main purpose is to identify if the chosen penetration strategy has a significant 
influence on the marketing policies and strategies implemented by the hotels belonging to an international hotel chain in Romania.

The research objectives are as follows:

(1) To identify the way in which the hotels operate after running under the umbrella of a hotel chain.

(2) To identify the balance between standardization and adaptation of implemented marketing mix strategies of the hotels belonging to an international chain in Romania.

(3) To study the correlation between penetration strategies and different marketing mix strategies.

\section{RESULTS AND DISCUSSIONS}

Penetration strategies used by all international hotel chains in Romania (\% from the total number of hotel chains) are presented in Figure 1. The strategies used most often by international hotel chains to penetrate a foreign market are the franchise and the management contract (Erramilli, Agarwal, Dev, 2002; Guillet, Zhang, Gao, 2011) and this pattern can be identified also on the Romanian market. More than $50 \%$ of the hotels (29) are franchises, 14 of them are functioning under a management contract, $\eta$ hotels are foreign direct investments and in Romania exists just a hotel witch has a leased contract.

Figure 1.: Penetration strategies used by international hotel chains to enter the Romanian market

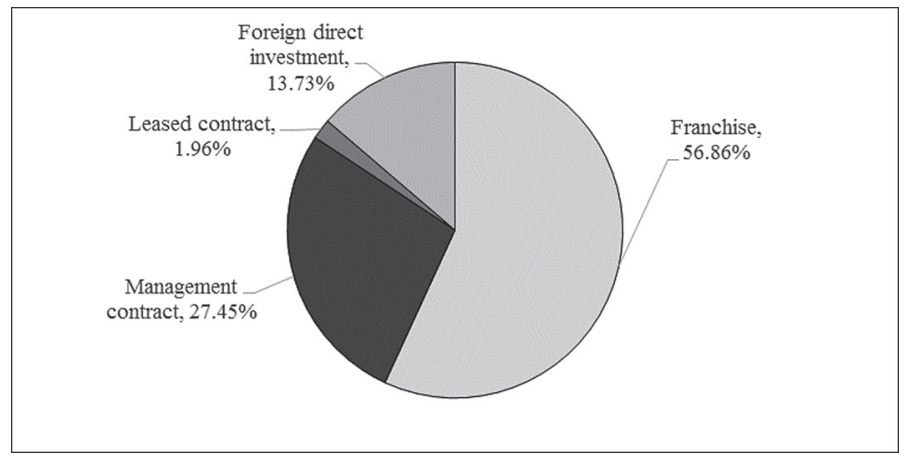

Source: Author's calculation

When entering a new market, the internationalization strategy chosen by hotels vary, being influenced by the amount of financial involvement, the level of desired operational control and the level of assumed risk (Chen and Dimou, 2005; Cristureanu, 2006). The chains which use as penetration strategies the foreign direct investment and the management contracts will want to have a high operational control and 
those with franchises will want to have an average one (Contractor and Kundu, 1998; Cristureanu 2006).

In Romania, the majority of the hotels belonging to international hotel chains are franchises or use management contracts. As a result of the analyse made for all the $5^{1}$ hotels, belonging to the 21 international hotel chains present on the Romanian market, 38 are continuing the activity by abiding the norms established in the contract and 13 by abiding the norms established mutually with the international chain (Figure 2.).

Figure 2.: Hotels' ways of operating after entering into an international chain

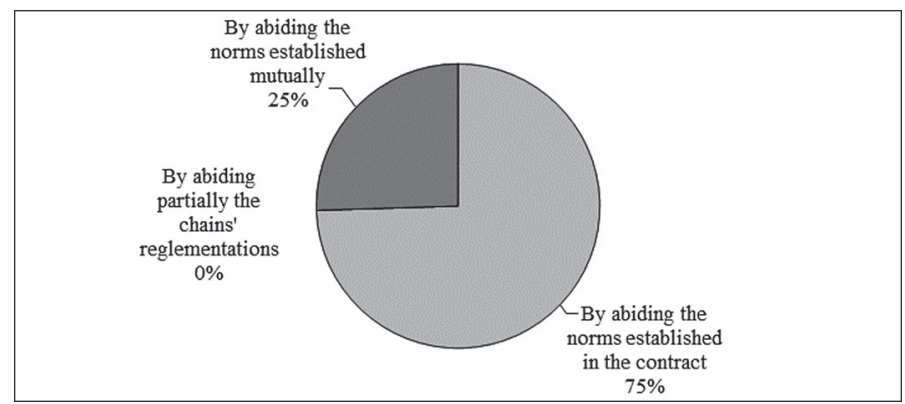

Source: Author's calculation

Analyzing this result in correlation with the penetration strategies used by the international hotel chains on the Romanian market, from all the hotels that operate by abiding the norms established in the contract, 19 are franchises, 13 use as penetration strategy the management contract, there is a leased contract and 5 foreign direct investments. From those hotels which operate by abiding the norms established mutually, 10 are franchises, one is a management contract and there are two foreign direct investments (Figure 3.).

Figure 3.: Penetration strategies used by the hotels that belong to an international hotel chain

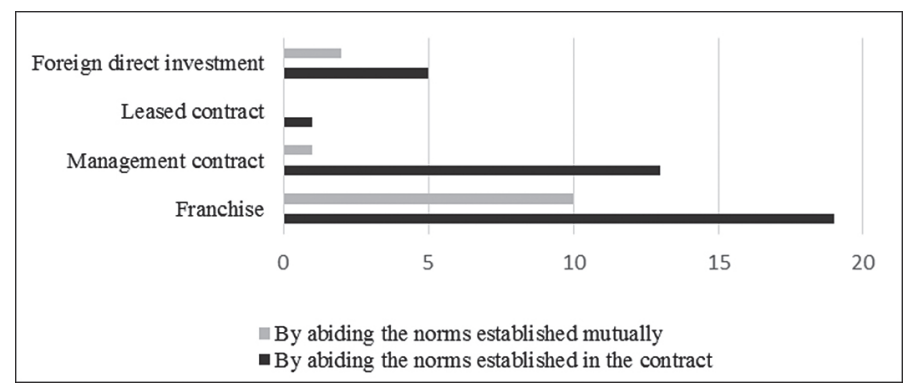

Source: Author's calculation 
The study revealed that the management contracts involve more imposed norms. From these $5^{1}$ hotels belonging to international chains, 40 are offering services based on the contract regulations, 31 depending on the particularities of each structure and $\eta$ based on the negotiated results.

The services' quality is evaluated using questionnaires addressed especially to the clients. The questionnaires are also addressed to the employees and to the business partners. The evaluation is considered when the hotel decides, but also when the international chain wants that.

Regarding the financial investment of hotel chains, those which use as penetration strategy the foreign direct investment have a high financial involvement, those that use management contracts have a low one and those with franchises will have an average one (Contractor and Kundu, 1998; Cristureanu 2006). Because of that, the hotel chains will influence in a different way the hotels, how to establish their prices. 29 hotels have the pricing strategies set less than $50 \%$ by the international chain, 12 hotels established between $51 \%-80 \%, 6$ hotels between $81 \%-99 \%$ by the international chain and 4 , that have the prices established 100\% by the international chain. From those which have the biggest freedom of decision, 27 are franchises, one is management contract and one foreign direct investment. From those 12 hotels, which have the pricing strategies established between $5^{1} \%-80 \%$ by the international chain, 8 are using the management contract, 2 are franchises and 2 are foreign direct investments (Figure 4.).

Figure 4.: Pricing strategies used by the hotels belonging to international chains

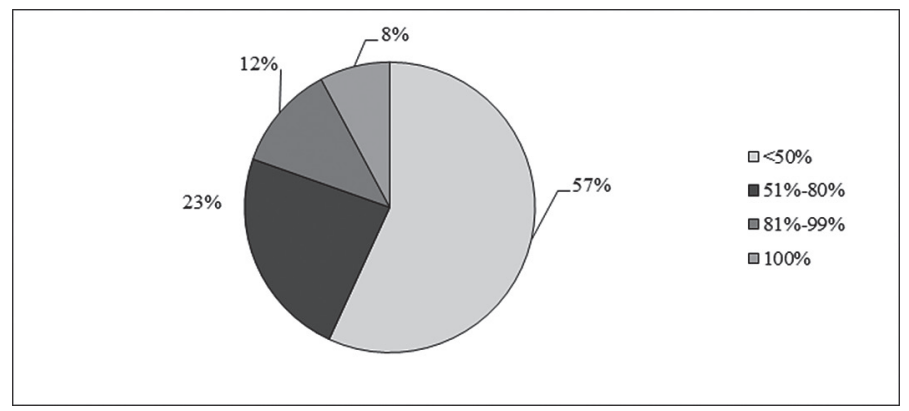

Source: Author's calculation

It can be observed that the majority of the hotels which are implementing the pricing strategies established less than $50 \%$ by the international chain are franchises (93\%). This happens because the international chain doesn't have a very high financial involvement, and in this case the franchisor wants to get the franchise fee. If the pricing strategies are established between $51 \%-80 \%$ or between $81 \%-99 \%$, the predominant penetration strategy is the management contract $(67 \%)$. In this case, the hotel chains want to have the same standards and similar pieces in all the hotels, all over the world. When the pricing strategies are established 100\% by the chain, 
in this situation it is the foreign direct investment the predominant strategy $(75 \%)$ (Figure 5.). The explanation is that the chains have a high financial involvement, and because of that they will take the decisions.

Figure 5.: Distribution of pricing strategies depending on the penetration strategies used by each hotel that belongs to an international chain

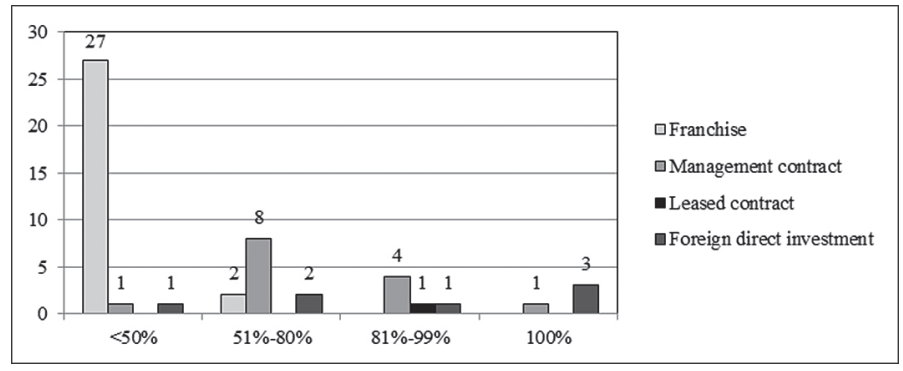

Source: Author's calculation

Using the coefficients Phi and Cramer V the research wanted to study if there is a connection between the penetration strategy and the strategies for the extended marketing mix elements used by each hotel. The null hypothesis is: „The extended marketing mix elements used by the hotels belonging to international chains are not influenced by the penetration strategies used in this country". In respect with the price, the Cramer V coefficient is $0,5^{8} 7$ and the research reveals a strong correlation between these variables. Because $\mathrm{p}<0,001$ the correlation between the penetration strategy and the pricing strategy used by each hotel is statistically significant. For the rest of the marketing mix elements were obtained values statistically insignificant.

Hotels use both own distribution channels and the channels belonging to the parent chain, and intermediaries also (Figure 6.). In this case, the hotels will use both standardized channels but also will adapt to the market.

Figure 6.: Distribution channels used by hotels belonging to international hotel chains

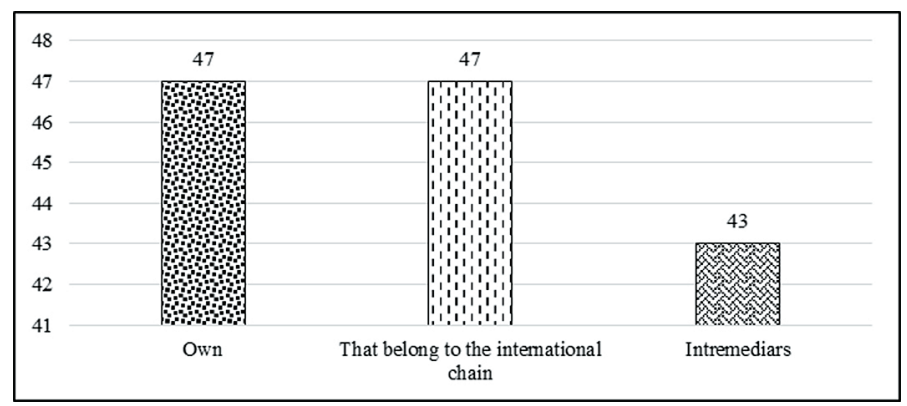

Source: Author's calculation 
Among the hotels that use their own distribution channels, 27 have a franchise contract, 14 a management contract, 5 are foreign direct investment and one leased contract. Channels belonging to the parent chain are used by 27 franchised hotels, 13 operate under management contract, 6 are foreign direct investment and there is also one leased contract. 24 franchised hotels, 12 hotels operating with a management contract, 6 foreign direct investment and one leasing contract use intermediaries in distribution strategy (Figure 7.).

Figure 7.: Distribution channels used by the hotels correlated with penetration strategies

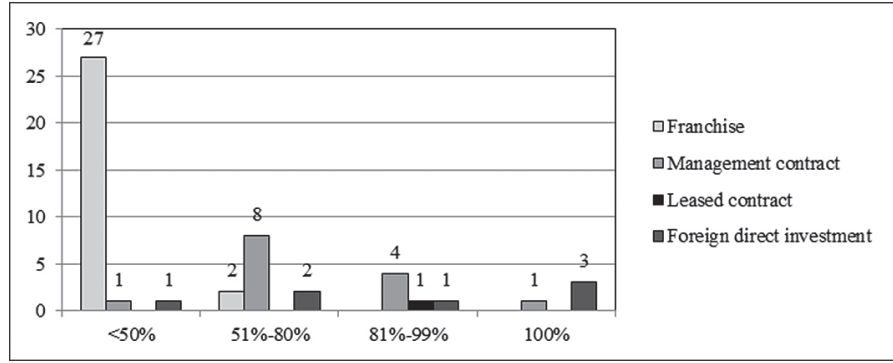

Source: Author's calculation

Global promotion strategies are implemented in 4,2 hotels, regional strategies by 41 and local promotion strategies also by 41 hotels (Figure 8 .). These promotion strategies are used by the hotels to address themselves to consumers at international level, but also at national one.

Figure 8.: The promotional activities level of implementation used by hotels belonging to international hotel chains

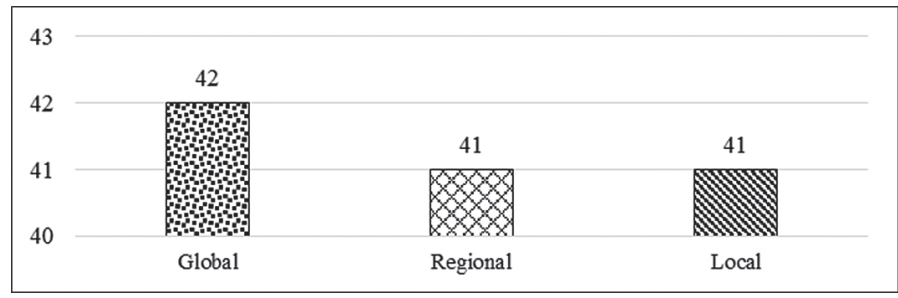

Source: Author's calculation

The obtained results correlated with penetration strategies used by the hotels are presented in Figure 9. From all $5^{1}$ hotels, 30 underlined they use all three ways of promotion. Among them 18 are franchises, 9 operating under a management contract, there are 2 foreign direct investments and one leased contract. 
Figure 9.: Promotion strategies used by hotels correlated with penetration strategies

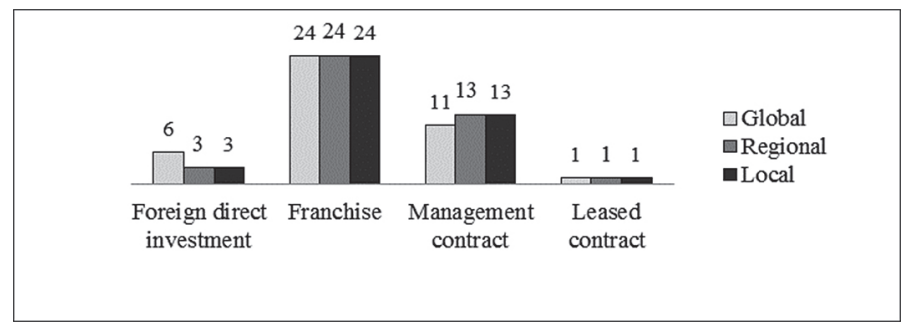

Source: Author's calculation

About the human resources policy, the majority of the hotels $(40)$ have the possibility to decide some elements such as the salary, bonus, number of employees, salary capital etc. 7 hotels have established it at international level and just 4 have negotiated (Figure 10.).

Figure 10.: The human resources policy used by hotels belonging to international hotel chains

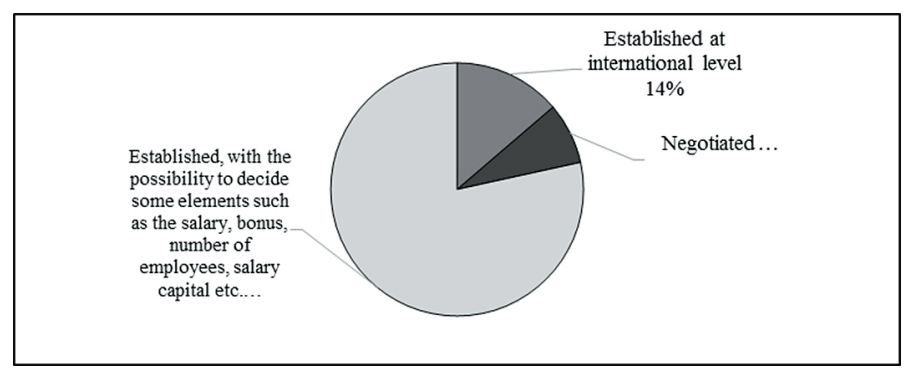

Source: Author's calculation

From the 40 hotels, which are having an established human resources policy, but with the possibility to decide some elements, the majority are franchises (25 hotels). Also, almost all the hotels that have a management contract use this policy (11 hotels from 14). There are 3 foreign direct investments and one leased contract (Figure 11.).

Figure 11.: The human resources policy used by hotels correlated with penetration strategies

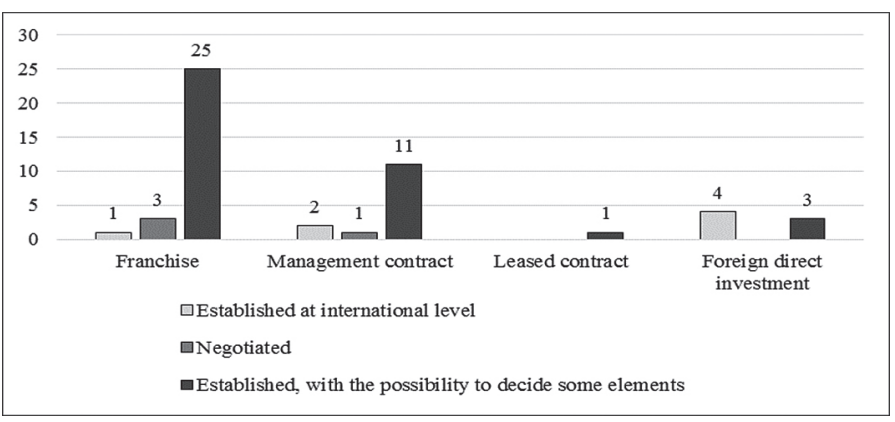

Source: Author's calculation 
The potential risk is also a very important criterion, taken into consideration by the hotel chains. Those chains that use foreign direct investment as penetration strategy have a high potential risk, those that use management contracts have a low one and those with franchises will have an average one (Contractor and Kundu, 1998; Cristureanu 2006). Because of that, the hotel chains will be involved in the decision making process.

Regarding the ways of establishing the offered services, 40 of the hotels have contractual regulations. From those 40 hotels, 20 take into consideration also the particularities of each accommodation structure and 4 hotels have also negotiated results (Figure 12.).

Figure 12.: Ways of establishing services offered by hotels belonging to international hotel chains

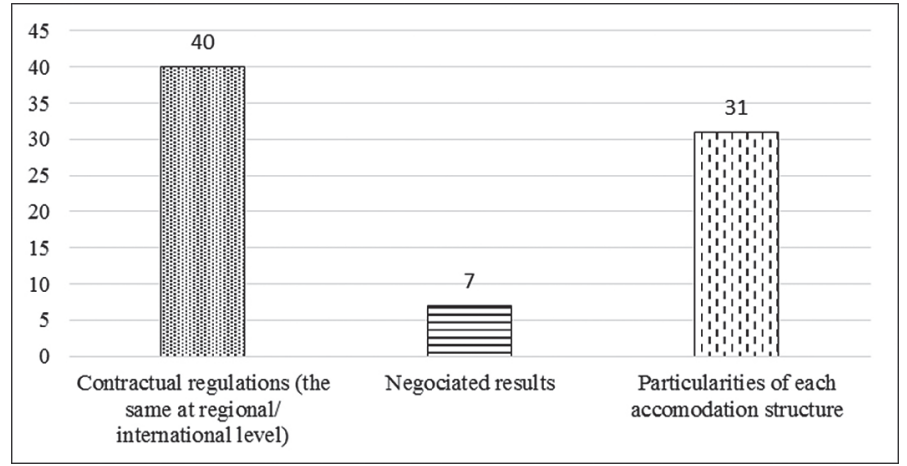

Source: Author's calculation

Among the hotels that use contractual regulations, 19 are franchises, 14 have a management contract, one a leased contract and 6 are foreign direct investments (Figure 13.). It is clear to observe the fact that 70\% from the hotels operating with a management contract have contractual regulations (the same at regional/ international level) and that is happening because the hotel chain wants to have the same quality of services all-over the world.

Figure 13.: Ways of establishing services offered by hotels correlated with penetration strategies

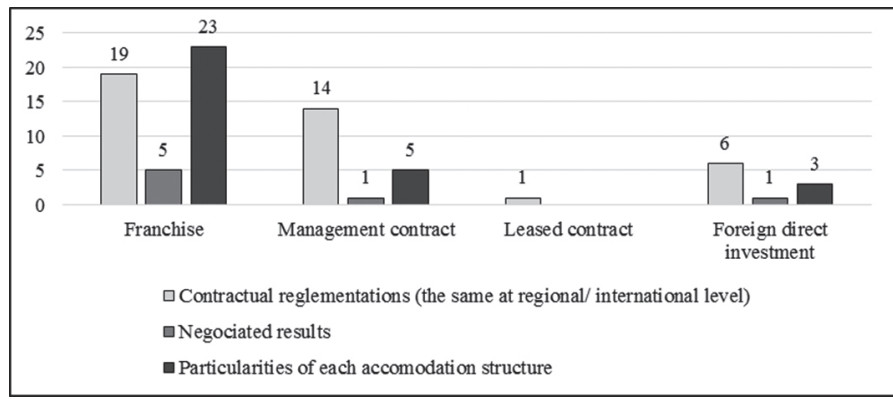

Source: Author's calculation 
The study reveals that all the $5^{1}$ hotels apply norms and standardized procedures regarding the quality of the services.

From all $5^{1}$ hotels belonging to an international chain, $4_{1} 1$ have an internal audit yearly, 9 of them just quarterly and just one hotel has it monthly (Figure 14.).

Figure 14.: Periodicity of the internal audit in hotels belonging to international hotel chains

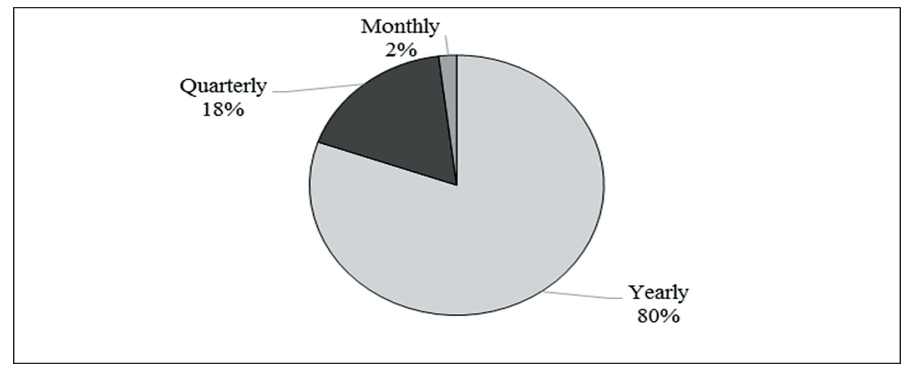

Source: Author's calculation

More than a half $(57 \%)$ from the hotels which are foreign direct investments have the internal audit more than one time each year. This is happening because the chains which have entered on the Romanian market with this penetration strategy are small ones, with not so many hotels and with the possibility to verify more often the hotels (Figure 15.). Regarding the internal audit for the franchises, just one hotel has the quarterly, all the rest have it yearly.

Figure 15.: Periodicity of internal audit in hotels correlated with penetration strategies

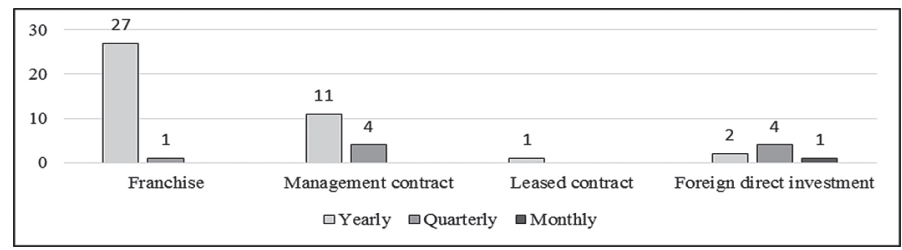

Source: Author's calculation

Almost all the hotels ( 47 hotels) belonging to an international chain think that the international visibility is an important advantage. Also, the increasing number of clients and the support given by the mother chain are also advantages taken into consideration by a hotel who wants to be part of an international chain. Just 23 of the hotels consider that belonging to a chain offers some financial advantages (Figure 16.). 
Figure 16.: Advantages of belonging to an international hotel chain

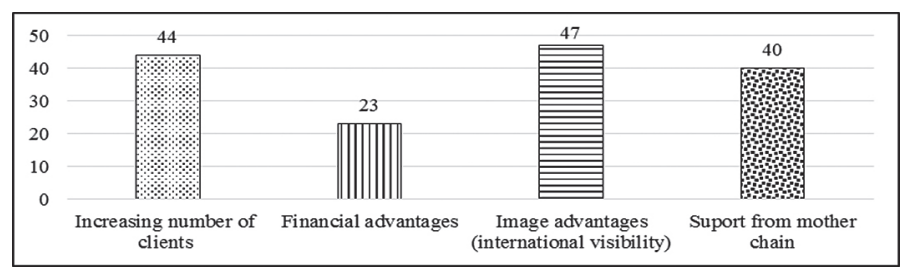

Source: Author's calculation

Regarding the correlation between the penetration strategies and the advantages of belonging to an international chain, there is a significant difference for the franchises. 28 from the franchised hotels consider an advantage the increasing number of clients, 27 the international visibility, 24 , the support from the mother chain but just 10 of them consider that belonging to an international chain will bring them financial advantages (Figure 17.).

Figure 17.: Advantages of hotels belonging to an international hotel chain correlated with penetration strategies

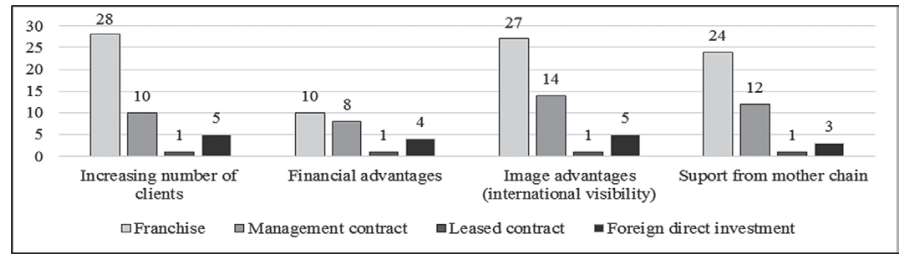

Source: Author's calculation

\section{CONCLUSION}

The majority of the hotels belonging to international hotel chains present on the Romanian market are franchises and management contracts. Most hotels in Romania, after entered under the umbrella of an international chain, operate by abiding the norms established by contract. From these, most are franchises. This is why the products/ services are agreed based on contractual regulations, and taking into account the peculiarities of the existing structure.

Regarding the pricing strategies, the situation is slightly different. Thus, most franchised hotels have the pricing strategies set by the parent chain at a rate of less than $50 \%$, because this type of strategy does not involve a high control and risk for the international chain. The higher the risk, the investment and the control are the more hotel chain influences pricing strategies. If one consider management contract, the parent chain can influence pricing strategies at a rate 
between $5^{1} \%-80 \%$. If the hotel chain influence in formulating pricing strategies is $100 \%$ than the hotel works as foreign direct investment.

In terms of distribution strategy, hotels belonging to international chains use their own channels but also the parent chain channels. Hotels address both Romanian customers and foreign ones. Finally, hotels can use intermediaries too.

The promotion strategy takes into account global, regional and local issues encountered. In this respect, the implementation takes particularly into account the specificities of local tourism demand, but also those of foreign tourism demand.

Regarding the personnel, the majority of the hotels have the possibility to decide internal elements such as the salary, bonus, number of employees, salary capital and so on. This situation is present in almost all the hotels that have a management contract (11 hotels from 14).

In terms of process, the study reveals that all the $5^{1}$ hotels apply norms and standardized procedures regarding the quality of the services. The majority of the hotels have contractual regulations (the same at international/ regional level).

The study shows that the most expected advantage for a hotel that belongs to an international chain is the visibility at international level. Hotels consider this image advantages as being some physical evidences incorporated in their offer.

Were tested correlations between the penetration strategies and the extended marketing mix strategies in order to identify connections between these variables. It has been statistically proven that the pricing strategies represent the only variable influenced by the penetration strategies.

The research reveals that the strategies for products, processes and some elements incorporated in physical evidences can be considered mainly standardized, while, variables like pricing, distribution, promotion and personnel are mainly adapted to the foreign market expectations and requirements.

The present study regarding the marketing mix strategies used by the hotels in Romania belonging to international chains has some limitations that can turn into future research. The most important limitation is related to the small number of questionnaires implemented. The investigated population has included just $5^{1}$ research units, which are for the moment all the hotels from Romania that are part of an international hotel chain.

The research offers a support in understanding perceptions and actions of hotels running under the umbrella of a hotel chain, upon the tourism industry in Romania, but it is impossible to extend the results to other countries or at regional or international level. Another important limitation appears because of the people that answered to this questionnaire. The questionnaire was applied also per email and for those situations it is impossible to be sure if the hotel managers answered.

Nevertheless this research expands the theoretical knowledge about the Romanian hotels industry, with a main focus on the marketing mix strategies of international hotel chains. Moreover, the findings of this paper are beneficial for local businesses and also for international hotel chains as providing a practical insight on 
how companies operate in the Romanian market in relation to their competitors. In addition to filling a research gap in the academic field, the study contributes with practical implications for hotel managers in terms of penetration and marketing mix strategies for international hotel chain.

However, there is space and need for further research on the related topic. Moreover, the hotel industry in Romania is constantly changing and developing, as new local units and international hotel chains are entering the market. Therefore, the competition on the Romanian market will continue to grow determining marketing decisions to become more important for the performance of the hotels. Some future research might concentrate more precisely on what local factors of the Romanian market are taken into consideration by hotels when deciding whether to develop standardized or customized strategies and also combining both customers' and companies' perspectives on marketing strategies within the market. Also it will be important to find out if the international hotel chains are using the same marketing mix strategies in other parts of the world and to make a comparison between Romania and different countries or markets. 


\section{REFERENCES:}

Bradley, F. Marketing international. București: Editura Teora, (2001)

Booms, B.H. and Bitner, B.J. "Marketing strategies and organisation structures for service firms." In Marketing of services, edited by J. Donnelly and W. R. George, 47-51. Chicago: American Marketing Association, (1980)

Brouthers, K.D. and Brouthers, L.E. "Why Service and Manufacturing Entry Mode Choices Differ: The Influence of Transaction Cost Factors, Risk and Trust." Journal of Management Studies, 4.0 (2003): 11791204

Chen, J.J. and Dimou, I. "Expansion strategy of international hotel firms." Journal of Business Research, $5^{8}$ (2005): $1730-1740$

Chen, L.Y. "TCE Mode Selection Criteria and Performance." Journal of American Academy of Business, 11 (2007): $244-252$

Contractor, F.J. and Kundu, S.K. "Modal Choice in a World of Alliances: Analyzing Organizational Forms in the International Hotel Sector." Journal of International Business Studies, 29 (1998): 325-358

Cosma, S., Fleșeriu, C.and Bota, M. "Hotel chain's strategic options to penetrate the Romanian market.", Amfiteatrul economic, XVI (2014): $1352-1365$

Cristureanu, C. Strategii si tranzacatii in turismul international. București: C.H. Beck, (2006)

Erramilli, M.K., Agarwal, S. and Dev, C.S. "Choice between non-equity entry modes: An organizational capability perspective." Journal of International Business Studies, 33 (2002): 223-242

Guillet, B.D., Zhang, H.Q. and Gao, B.W. "Interpreting the mind of multinational hotel investors: Future trends and implications in China." International Journal of Hospitality Management, 3० (2011): 222-232

Gilligan, C. and Wilson, R.M.S. Strategic Marketing Management: Planning, Implementation and Control. Oxford: Elsevier Butterworth-Heinemann, (2005)

Johansson, J.K. Global Marketing, Foreign Entry, Local Marketing \& Global Marketing. Boston: McGraw-Hill/ Irwin series in marketing, (2006)

Schilke, O. Reimann, M. and Thomas, J.S. "When Does International Marketing Standardization Matter to Firm Performance?" Journal of International Marketing, 17 (2009): 24-4,6

Jones, P. Hillier, D. and Comfort, D. "Sustainability in the global hotel industry." International Journal of Contemporary Hospitality Management, 26 (2014): $5^{-17}$

Yu, Y. Byun, W. and Lee, T. J. “Critical issues of globalisation in the international hotel industry." Current Issues in Tourism, 17 (2014): 114,-118

Călăretu, V.B. "Development strategies for hotel chains." Proceedings of the International Conference on Business Excellence, 1 (2011): 95-98

Cline, R. S. Hospitality adjusts to globalization, 2002. Accessed November 29, 2015, http://www.hotelonline.com/Trends/Andersen/global.html

Aliouche, E. H. and Schlentrich, U. A. "Towards a strategic model of global franchise expansion." Journal of Retailing, 87 (2011): $345^{-365}$

Wilson, A., Zeithaml, V. A., Bitner, M. J. and Gremler, D.D. Service Marketing: Integrating Customer Focus Across the Firm. London: McGraw-Hill Education, (2012) 
Lee, T. J. "Role of hotel design in enhancing destination branding." Annals of Tourism Research, 38 (2011): $7^{\circ-7}$-11 $^{11}$

Sutthijakra, S. "Managing service subsidiaries through an innovation perspective: a case of standard interpretation in multinational hotels", Service Industries Journal, 31 (2011): $545^{-5} 55^{8}$ 
